\title{
Antibacterial and smear layer removal capability of oregano extract solution
}

\author{
Evren Ok ${ }^{1}$, Necdet Adanir², Tuba Ozturk \begin{abstract}
University, Izmir, Turkiye,
2Department of Endodontics, Faculty of Dentistry, Suleyman Demirel University, Isparta, Turkiye,

${ }^{3}$ Department of Microbiology, Faculty of Medicine, Suleyman Demirel University, Isparta, Turkiye
\end{abstract} \\ 'Department of Endodontics, Faculty of Dentistry, Sifa
}

Correspondence: Dr. Evren Ok

Email: dh.evrenok@hotmail.com

\section{ABSTRACT}

Objective: The aim of this in vitro study was to evaluate the antimicrobial effect of oregano extract solution (OES) against Enterococcus faecalis within root canals and dentin tubules, and its effect on smear layer. Materials and Methods: A total of 180 human maxillary central incisors was selected. After removal of coronal part of the teeth, root canals were prepared using ProTaper rotary files (Dentsply, Tulsa Endodontics, OK, USA) to \#F3 with the crown-down manner. The roots were randomly assigned to 15 groups ( $n=12$ for each). In the first seven groups, the antimicrobial effects of the test groups were evaluated. Suspensions of E. faecalis cultures were adjusted to $1.0 \mathrm{McFarland}\left(1 \times 10^{8}\right.$ colony-forming unit $\left.[\mathrm{CFU}] / \mathrm{ml}\right)$, and sterilized teeth were placed in Eppendorf tubes and kept at $37^{\circ} \mathrm{C}$ for 4 weeks. Samples were then taken from the root canals before irrigation using three sterile paper points. Dentin samples were taken from root canals with ProTaper \#F4 and \#F5 series rotary instruments after irrigation. The aliquots of samples were placed into the brain heart infusion and incubated at $37^{\circ} \mathrm{C}$ for $48 \mathrm{~h}$ and then the CFUs were counted. In the other eight groups, the efficacy of the irrigation solutions on removing the smear layer was evaluated using scanning electron microscope (Leo 440, Oxford Microscopy Ltd., Cambridge, England) analysis. Statistical evaluation of the microbiological data was performed using the Kruskall-Wallis and MannWitney U-test $(P<0.05)$. Results: There was a statistically difference between the groups $(P<0.05)$. Chlorhexidine gluconate (CHX), $5 \%$ and $2 \%$ OES wasn't found to be statistically significant regarding their antibacterial activities against E. faecalis $(P>0.05) .1 \%$ OES and $\mathrm{NaOCl}$ showed similar antimicrobial effect $(P>0.05)$, and $1 \%$ OES and $\mathrm{NaOCl}$ were better than ethylenediaminetetraacetic acid (EDTA) and saline $(P<0.05)$ but not as successful as CHX. According to the results obtained from dentin, CHX is the most effective solution within dentinal tubules. Different concentrations of OES were not achieved smear layer removal alone but OES in conjunction with 17\% EDTA was the final irrigating solution achieved the smear layer removal without dentin erosion. Conclusions: Within the limitations of this study, OES appears to be a possible alternative to $\mathrm{NaOCl}$ as a root canal irrigant on the eradication of E. faecalis and removal of smear layer.

Key words: Antimicrobial effect, chlorhexidine gluconate, Enterococcus faecalis, irrigation solution, $\mathrm{NaOCl}$, oregano extract solution, smear layer

\section{INTRODUCTION}

The success of a root canal treatment relies on the proper removal of pulpal remnants, bacteria, and their products from the root canal system. ${ }^{[1]}$ Mechanical preparation alone is not able to remove the pulpal remnants and bacteria effectively from root canals due to the fact that microorganisms are present in all parts of the root canal system, especially in anastomoses, lateral canals, and dentin tubules. ${ }^{[2]}$ Effectively used irrigation in the root canal system is one of the most essential steps for the elimination of microorganisms from these locations. ${ }^{[3]}$

An ideal irrigation solution has to have a proper antibacterial and tissue dissolving effect on the necrotic pulp remnant and minimum toxic effect on the periapical tissue. $\mathrm{NaOCl}$ is the most commonly used root canal irrigation solution up to date due to its antimicrobial

How to cite this article: Ok E, Adanir N, Ozturk T. Antibacterial and smear layer removal capability of oregano extract solution. Eur J Dent 2015;9:20-4. 
effect and tissue dissolving properties, ${ }^{[4]}$ but it is harmful when put in contact with periapical tissue. ${ }^{[5-7]}$ Chlorhexidine gluconate $(\mathrm{CHX})$ is an alternative irrigation solution to $\mathrm{NaOCl}$ that has a wide range of antimicrobial activity against both Gram-positive and Gram-negative microorganisms, especially against Enterococcus faecalis..$^{[8]}$ However, a main disadvantage of CHX is its lack of organic tissue dissolution capabilities. Hence, other solutions have been experimented as alternative irrigation solutions to $\mathrm{NaOCl}$ and $\mathrm{CHX}$.

Origanum minutiflorum is a plant found throughout South-Western Anatolia, especially in Isparta, Turkey. The plant's extract, especially its oil, has an antimicrobial effect on many microorganisms. Dadalioglu and Evrendilek ${ }^{[9]}$ reported that O. minutiflorum has an antimicrobial effect on Escherichia coli, Listeria monocytogenes, Salmonella typhimurium, and Staphylococcus aureus. Similarly, Baydar et al..$^{[10]}$ found that $1-2 \%$ origanum oil has an antimicrobial effect on $E$. faecalis.

Up to date, there were no in vivo or in vitro studies of oregano extract solution (OES) as a root canal irrigant in the literature. Therefore, the aim of this in vitro study was to evaluate the antimicrobial effect of OES as an intracanal irrigant against E. faecalis using bacteria culturing method, and its effect to the smear layer using a scanning electron microscope (SEM) (Leo 440, Oxford Microscopy Ltd., Cambridge, England).

\section{MATERIALS AND METHODS}

The method followed was a modification of the technique described previously by Berber et al. ${ }^{[11]} \mathrm{A}$ total of 180 extracted human mature maxillary central incisor teeth with a single root and without root resorption was selected. The crowns were removed with a water-cooled diamond saw (Buehler Ltd., Lake Bluff, IL, USA) to leave uniform $15 \mathrm{~mm}$ apical sections of root.

The root canal instrumentation was done using an endodontic X-Smart micro-motor (Dentsply-Maillerfer, Ballaigues, Switzerland) at a speed of $350 \mathrm{rpm}$ with ProTaper NiTi rotary files (Dentsply, Tulsa Endodontics, OK, USA) to size \#F3 with the crown-down manner. The 180 specimens were randomly assigned to 15 groups ( $n=12$ for each), antimicrobial evaluation was performed in the first seven groups. In the other eight groups, effect of the solutions on the smear layer was studied.

The smear layer was removed in the first seven groups with $3 \mathrm{ml} \mathrm{17 \%}$ ethylenediaminetetraacetic acid (EDTA) (Merck KGaA, Darmstadt, Germany) for 1-min, followed by $3 \mathrm{ml} \mathrm{5.25 \%} \mathrm{NaOCl}$ (Wizard, Ankara, Turkey) for 1-min, and then $5 \mathrm{ml}$ distillate water for 1-min as outlined by Teixeira et al. ${ }^{[12]}$ Samples were after that autoclaved at $121^{\circ} \mathrm{C}$ at $1 \mathrm{~atm}$ for $20 \mathrm{~min}$, and then placed into glass tubes containing $5 \mathrm{ml}$ of brain heart infusion (BHI) broth medium (BHI, Oxoid, Basingstoke, UK).

\section{Cultivation of the Enterococcus faecalis and contamination of samples}

Pure cultures of E. faecalis (ATCC 29212) cultures were previously cultivated in a BHI broth for $24 \mathrm{~h}$ and then cultured in 5\% defibrinated sheep blood and $\mathrm{BHI}$ agar plates. Suspensions of this bacterium were adjusted to 1.0 McFarland $\left(1 \times 10^{8}\right.$ colony-forming units [CFU]/ $\mathrm{ml})$ and sterilized teeth were placed in Eppendorf tubes (Eppendorf AG, Hamburg, Germany) and kept at $37^{\circ} \mathrm{C}$ for 4 weeks.

Sterile pipettes were used to remove $5 \mathrm{ml}$ of sterile BHI and to replace it with $5 \mathrm{ml}$ of the bacterial inoculum. The medium was changed every 7 days to avoid saturation and confirm the growth of E. faecalis. ${ }^{[13]}$ Four weeks later, the purity of the cultures was confirmed by Gram staining, catalase production.

\section{Microbial sampling of the root canals}

Samples were taken from the root canals before irrigation using three sterile paper points. After that, $6 \mathrm{ml}$ of each solution (Group 1: EDTA; Group 2: CHX; Groups 3-5: 1\%, 2\%, 5\% EOS, respectively; Group 6: $5.25 \% \mathrm{NaOCl}$; and Group 7: Sterile saline) was used for $2 \mathrm{~min}$ in each canal. ${ }^{[13]}$ After irrigation procures sterile paper points were placed into root canals for 1-min, and then transferred to Eppendorf tubes containing $1 \mathrm{ml} \mathrm{BHI} \mathrm{broth,} \mathrm{and} \mathrm{then} \mathrm{vortexed} \mathrm{for} \mathrm{1-min.} \mathrm{After}$ three times 10-fold serial dilutions were done for each sample, aliquots of $0.1 \mathrm{ml}$ were plated onto the $\mathrm{BHI}$ and blood agar plates combination and incubated at $37^{\circ} \mathrm{C}$ for $48 \mathrm{~h}$. Growing colonies were counted and recorded as CFU.

\section{Dentin samples of root canals}

Dentin samples were taken from root canals with ProTaper \#F4 and \#F5 series rotary instruments after irrigation. First, \#F4 rotary instruments were rotated into the dentin for $15 \mathrm{~s}$, and the collected dentin samples were transferred to the Eppendorf tubes containing $1 \mathrm{ml} \mathrm{BHI} \mathrm{broth.} \mathrm{This} \mathrm{was} \mathrm{then} \mathrm{repeated} \mathrm{with}$ the ProTaper \#F5 series. All samples were vortexed for 1-min, and then the Eppendorf tubes were incubated at $37^{\circ} \mathrm{C}$ for $48 \mathrm{~h}$. After two times 10 -fold serial dilutions were done for each sample, aliquots of $0.1 \mathrm{ml}$ were 
plated onto the $\mathrm{BHI}$ and blood agar plates combination and incubated at $37^{\circ} \mathrm{C}$ for $48 \mathrm{~h}$ and recorded as CFU.

\section{Scanning electron microscope evaluation}

Smear layer removal procedure was done as described by Teixeira et al. ${ }^{[12]}$

- Group 8: $3 \mathrm{ml}$ 5.25\% NaOCl for 1-min + $3 \mathrm{ml} 17 \%$ EDTA for 1-min $+5 \mathrm{ml}$ distilled water for 1-min

- Group 9: $3 \mathrm{ml}$ 1\% OES for 1-min + $5 \mathrm{ml}$ distilled water for 1-min

- Group 10: $3 \mathrm{ml}$ 2\% OES for 1-min + $5 \mathrm{ml}$ distilled water for 1-min

- Group 11: $3 \mathrm{ml}$ 5\% OES for 1-min + $5 \mathrm{ml}$ distilled water for 1-min

- Group 12:3 ml 1\% OES for 1-min + $3 \mathrm{ml}$ 17\% EDTA for 1-min $+5 \mathrm{ml}$ distilled water for 1-min

- Group 13: $3 \mathrm{ml}$ 2\% OES for 1-min + 3 ml 17\% EDTA for 1-min $+5 \mathrm{ml}$ distilled water for 1-min

- Group 14:3 ml 5\% OES for 1-min + $3 \mathrm{ml} 17 \%$ EDTA for 1-min $+5 \mathrm{ml}$ distilled water for 1-min

- Group 15: $3 \mathrm{ml}$ sterile saline for 1-min + $3 \mathrm{ml} 17 \%$ EDTA for 1-min $+5 \mathrm{ml}$ distilled water for 1-min.

A longitudinal groove on the buccal and lingual surfaces on each specimen was prepared on each specimen using a diamond disc (SS White, Lakewood, New Jersey, USA) at low speed and split into two halves. The specimens were dehydrated, held in a $50 \%, 75 \%, 85 \%$, and $96.5 \%$ ethyl alcohol solution, dried, mounted on metallic stubs, sputter-coated with a gold alloy (Polaron SC7620 Sputter Coater; VG Microtech Inc., Japan), and examined with a SEM (Leo 440, Oxford Microscopy Ltd., Cambridge, England) $\times 8,000$ magnification.

The data were statistically analyzed using the SAS (SAS Institute, Raleigh, NC, USA) computer program. Each CFU count was transformed to $\log _{10}$ to normalize the data before statistical evaluation. Statistical evaluation was done with the Kruskall-Wallis and Mann-Whitney U-test. The level of significance was set at $P<0.05$.

\section{RESULTS}

Statistical evaluation of the groups concerning the antimicrobial effectiveness of the irrigation solutions is shown in Table 1 . There was a statistically difference among the groups $(P<0.05)$. According to the results obtained in the root canal after irrigation, $\mathrm{CHX}$, $5 \%$ and $2 \%$ OES were not found to be statistically significant regarding their antibacterial activities against E. faecalis. $1 \%$ OES and $\mathrm{NaOCl}$ showed a similar antimicrobial effect $(P>0.05)$ and were not as successful as $\mathrm{CHX}(P<0.05)$.

\begin{tabular}{|c|c|c|c|c|}
\hline $\begin{array}{l}\text { Irrigation } \\
\text { solutions }\end{array}$ & $\begin{array}{c}\text { Before } \\
\text { irrigation }\end{array}$ & $\begin{array}{c}\text { After } \\
\text { irrigation }\end{array}$ & $\begin{array}{c}\text { Dentin } \\
\text { samples } \\
\text { \#F4 }\end{array}$ & $\begin{array}{l}\text { Dentin } \\
\text { samples } \\
\text { \#F5 }\end{array}$ \\
\hline EDTA & $6.567 \pm 0.494^{a}$ & $4.309 \pm 0.491^{a}$ & $4.046 \pm 0.189^{a}$ & $4.047 \pm 0.224^{a}$ \\
\hline $\mathrm{CHX}$ & $6.508 \pm 0.403^{a}$ & $0 \pm 0^{\mathrm{b}}$ & $0 \pm 0^{\mathrm{b}}$ & $0 \pm 0^{b}$ \\
\hline $1 \%$ OES & $6.287 \pm 0.976^{a}$ & $1.404 \pm 1.803^{\mathrm{cd}}$ & $4.205 \pm 0.071^{c}$ & $3.817 \pm 1.235^{a}$ \\
\hline $2 \%$ OES & $6.551 \pm 0.556^{a}$ & $0.391 \pm 0.926^{b c}$ & $4.159 \pm 0.094^{c}$ & $3.81 \pm 1.206^{a}$ \\
\hline $5 \%$ OES & $6.375 \pm 0.578^{a}$ & $0.383 \pm 0.904^{b c}$ & $4.068 \pm 0.266^{c}$ & $4.092 \pm 0.290^{a}$ \\
\hline $\mathrm{NaOCl}$ & $6.440 \pm 0.461^{a}$ & $2.308 \pm 1.739^{d}$ & $4.113 \pm 0.077^{c}$ & $4.137 \pm 0.079$ \\
\hline $\begin{array}{l}\text { Sterile } \\
\text { saline }\end{array}$ & $6.591 \pm 0.536^{a}$ & $3.756 \pm 1.349^{a}$ & $4.174 \pm 0.080^{c}$ & $4.147 \pm 0.075^{a}$ \\
\hline
\end{tabular}

*There is no statistically significant difference between shown in the same column and the values with the same superscript $(P>0.05)$. SD: Standard deviation, CFU: Colony-forming unit, CHX: Chlorhexidine gluconate, OES: Oregano extract solution

According to the results obtained from the dentin samples, CHX was the most effective solution compared to other groups $(P<0.05)$. CHX penetrated into the dentin tubules and eradicated all of the $E$. faecalis. No statistical difference was found between all OES groups and $5.25 \% \mathrm{NaOCl}$, which both could not penetrate into the dentin tubules.

According to the results obtained from the SEM evaluation, $1 \%$ OES, $2 \%$ OES, or $5 \%$ OES followed by $17 \%$ EDTA completely removed the smear layer without dentin erosion [Figure 1a-c]. However, \% OES, $2 \%$ OES, or $5 \%$ OES without $17 \%$ EDTA failed to remove the smear layer alone [Figure 2a-c]. Irrigation with $5.25 \% \mathrm{NaOCl}$ and $17 \%$ EDTA combination achieved the removal of the smear layer [Figure 3].

\section{DISCUSSION}

Enterococcus faecalis, a very persistent microorganism isolated from in infected teeth that invades deep into dentin tubules, was isolated in cases of failed root canal treatment. ${ }^{[14,15]}$ In the present study, E. faecalis was used to evaluate the antimicrobial efficiency of solutions. The results obtained from this study showed that $5.25 \% \mathrm{NaOCl}$ was effective against $E$. faecalis within root canals. There was no statistical difference was found between $1 \%$ OES and $5.25 \% \mathrm{NaOCl}(P>0.05)$ in terms of their effectiveness against $E$. faecalis in this study. But there was a statistically significant difference between the antimicrobial effect of $2 \%$ OES and $5 \% \mathrm{OES}$ and $5.25 \% \mathrm{NaOCl}(P<0.05)$. The present findings also indicate that in the eradication of E. faecalis, $\mathrm{NaOCl}$ was not as effective as $\mathrm{CHX}$. Onçag et al. ${ }^{[8]}$ found that $2 \% \mathrm{CHX}$ was significantly more effective against $E$. faecalis than $5.25 \% \mathrm{NaOCl}$. In our 


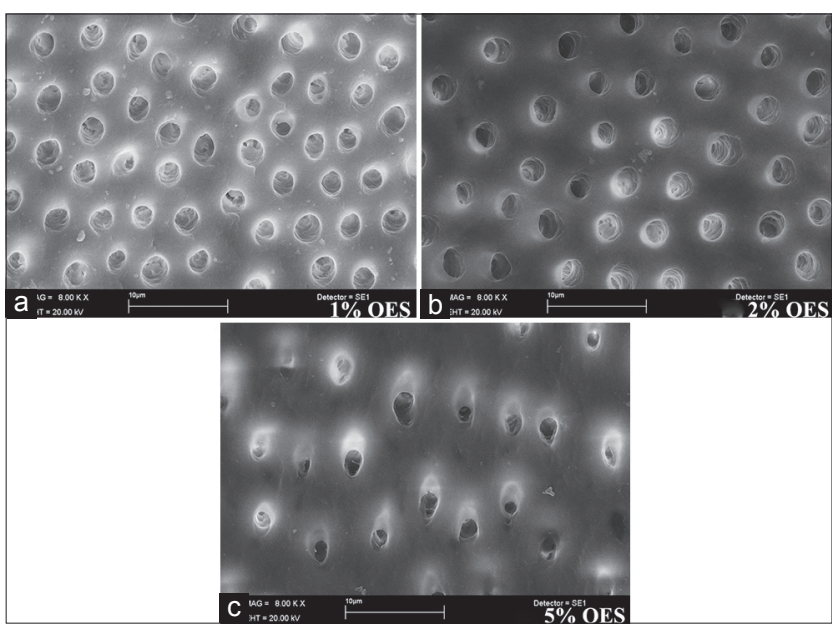

Figure 1: Scanning electron micrographs (a) 1\% oregano extract solution (OES) $+17 \%$ ethylenediaminetetraacetic acid (EDTA) (b) $2 \%$ OES $+17 \%$ EDTA (c) $5 \%$ OES $+17 \%$ EDTA

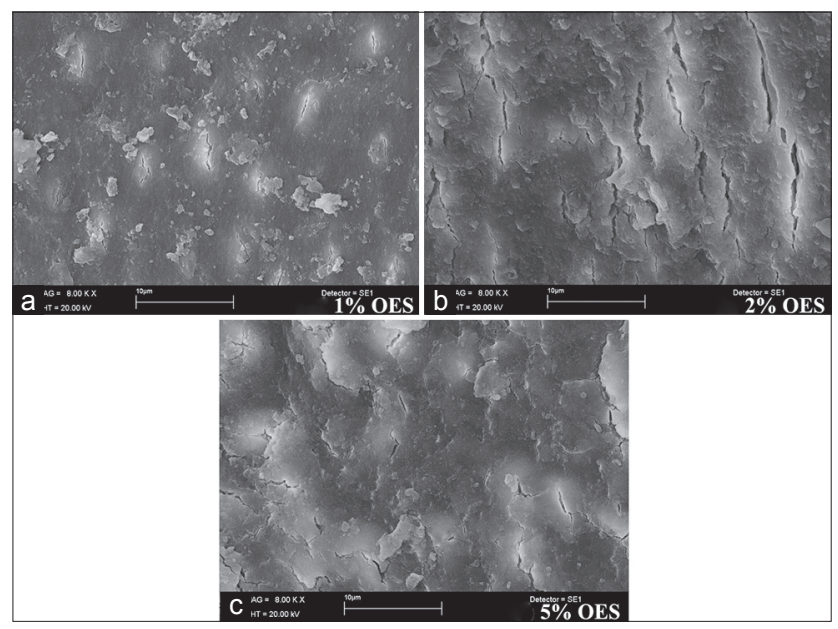

Figure 2: Scanning electron micrographs (a) 1\% oregano extract solution (OES) (b) $2 \%$ OES (c) $5 \%$ OES

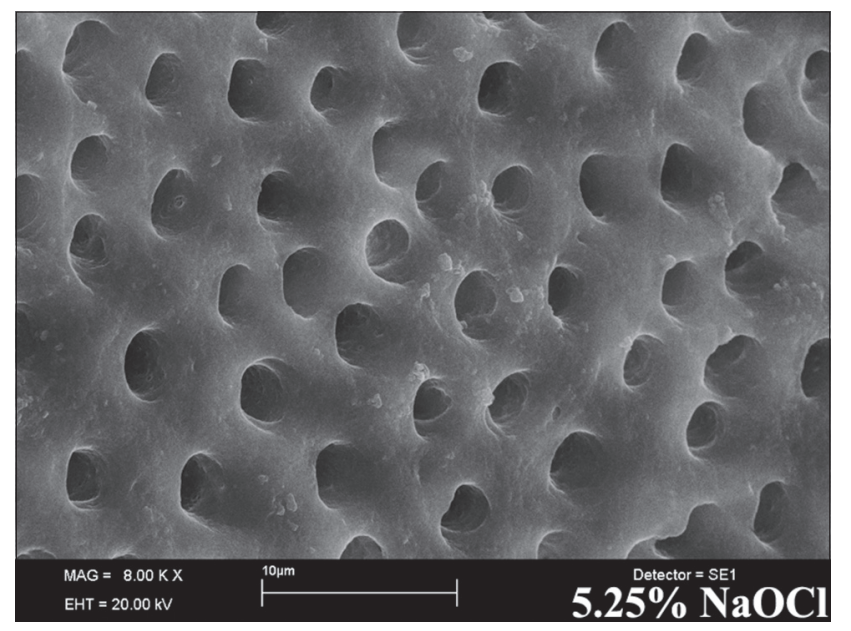

Figure 3: Scanning electron micrographs of $5.25 \mathrm{NaOCl}+17 \%$ ethylenediaminetetraacetic acid

study, CHX eradicated all of the E. faecalis from the root canal system and was significantly more effective than $5.25 \% \mathrm{NaOCl}(P<0.05)$. This result shows that our findings support the results of Onçag et al. ${ }^{[8]}$

Microorganisms may invade to the dentin tubules of both vital and necrotic pulp, but vital teeth may limit the invasion of the microorganism with a pulp defense system. ${ }^{[16]}$ Microorganisms that live in dentin tubules are an important risk factor in the success of the root canal treatment. ${ }^{[11,17]}$ Berber et al..$^{[11]}$ indicated that no statistical difference was found between $0.5 \%$ and $5.25 \%$ concentrations of $\mathrm{NaOCl}$ as a root canal irrigant. However, in regard to its antimicrobial effect on dentin tubules, $5.25 \% \mathrm{NaOCl}$ was evaluated as highly effective. Vahdaty et al. ${ }^{[18]}$ stated that $\mathrm{NaOCl}$ had an antimicrobial effect against $E$. faecalis in $500 \mu \mathrm{m}$ deep dentin tubules, and Gomes et al. ${ }^{[19]}$ found the same in $10 \mu \mathrm{m}$ deep dentin tubules. Mohammadi and Shahriari ${ }^{[20]}$ found that $\mathrm{NaOCl}$ had no antimicrobial effect when $\mathrm{CHX}$ had not penetrated deep into the dentin tubules, and Basrani et al. ${ }^{[21]}$ and Gomes et al. ${ }^{[19]}$ have stated that $2 \% \mathrm{CHX}$ completely eradicated $E$. faecalis from root canals and dentin tubules. Similarly, in our findings, $\mathrm{NaOCl}$ and $\mathrm{OES}$ could not penetrate into the dentin tubules, and $\mathrm{CHX}$ was highly effective against $E$. faecalis in the dentin tubules $(P<0.05)$. However, $2 \%$ and $5 \%$ OES more effectively eradicate $E$. faecalis than $5.25 \% \mathrm{NaOCl}$ in the root canals $(P<0.05)$.

In the present study, $\mathrm{NaOCl}$ and EDTA, combination was used to remove the smear layer. Although $\mathrm{NaOCl}$ was unsuccessful in removing the smear layer alone, it has been used for many years due to its capacity to act as a solvent of organic tissue. Beltz et al. ${ }^{[22]}$ stated that $5.25 \% \mathrm{NaOCl}$ dissolved over $90 \%$ of organic components, and that $17 \%$ EDTA dissolved above $70 \%$ of inorganic components. Several studies ${ }^{[23-25]}$ have stated that an EDTA and $\mathrm{NaOCl}$ combination has the ability to remove the smear layer without damaging dentin walls. In the present study $5.25 \%$ $\mathrm{NaOCl}$ and $17 \%$ EDTA combination was used as a positive control group, it was found that the smear layer was completely removed, all dentin tubules were opened, and the root canals were clean in all parts. Contrary to the findings of Serper and Calt, ${ }^{[26]}$ no intertubuler and peritubuler erosion was established. The results of our findings were similar to many articles in literature. ${ }^{[12,23,25,27]}$ This difference may have arisen from the use of a 1-min $10 \mathrm{ml} \mathrm{17 \%} \mathrm{EDTA}$ solution in their study. ${ }^{[26]}$ Similarly, Ballal et al. ${ }^{[28]}$ reported that using $5 \mathrm{ml} \mathrm{17 \%}$ EDTA did not cause erosion in peritubuler dentin.

Alternatively to $\mathrm{NaOCl}$, different OES concentrations were also used alone as well as combined with EDTA 
to remove the smear layer, and found that OES could not remove the smear layer alone [Figure 2]. However, when the OES and EDTA combination was used, it removed the smear layer and opened dentin tubules without erosion. The combination of $1 \%, 2 \%$ or $5 \%$ OES and $17 \%$ EDTA removed surface smear layer, dentin tubules were opened in the coronal, middle, and apical part [Figure 1]. Torabinejad et al. ${ }^{[29]}$ reported that the opening of the dentin tubules was greater in the coronal third than the apical third in connection to insufficient irrigation due to the small diameter of the apical part. Similarly, in this study, all solutions that removed the smear layer led to dentin tubules that were opened more in the coronal part than the apical part.

\section{CONCLUSION}

Within the limitations of this study, 1\% OES and 5.25\% $\mathrm{NaOCl}$ have the same antimicrobial activity against E. Feacalis and $2 \%$ or $5 \%$ OES had more effective antibacterial action than $5.25 \% \mathrm{NaOCl}$. OES and $\mathrm{NaOCl}$ have the same effect on the removing of the organic compound of the smear layer. Therefore, OES appears a possible alternative to $5.25 \% \mathrm{NaOCl}$ as a root canal irrigant.

\section{REFERENCES}

1. Byström A, Sundqvist G. Bacteriologic evaluation of the efficacy of mechanical root canal instrumentation in endodontic therapy. Scand J Dent Res 1981;89:321-8.

2. Siqueira JF Jr, Lima KC, Magalhães FA, Lopes HP, de Uzeda M. Mechanical reduction of the bacterial population in the root canal by three instrumentation techniques. J Endod 1999;25:332-5.

3. Bystrom A, Sundqvist G. The antibacterial action of sodium hypochlorite and EDTA in 60 cases of endodontic therapy. Int Endod J 1985;18:35-40.

4. Siqueira JF Jr, Machado AG, Silveira RM, Lopes HP, de Uzeda M. Evaluation of the effectiveness of sodium hypochlorite used with three irrigation methods in the elimination of Enterococcus faecalis from the root canal, in vitro. Int Endod J 1997;30:279-82.

5. Gatot A, Arbelle J, Leiberman A, Yanai-Inbar I. Effects of sodium hypochlorite on soft tissues after its inadvertent injection beyond the root apex. J Endod 1991;17:573-4.

6. Brown DC, Moore BK, Brown CE Jr, Newton CW. An in vitro study of apical extrusion of sodium hypochlorite during endodontic canal preparation. J Endod 1995;21:587-91.

7. Pashley EL, Birdsong NL, Bowman K, Pashley DH. Cytotoxic effects of $\mathrm{NaOCl}$ on vital tissue. J Endod 1985;11:525-8.

8. Onçag O, Hosgör M, Hilmioglu S, Zekioglu O, Eronat C, Burhanoglu D. Comparison of antibacterial and toxic effects of various root canal irrigants. Int Endod J 2003;36:423-32.

9. Dadalioglu I, Evrendilek GA. Chemical compositions and antibacterial effects of essential oils of Turkish oregano (Origanum minutiflorum), bay laurel (Laurus nobilis), Spanish lavender (Lavandula stoechas L.), and fennel (Foeniculum vulgare) on common foodborne pathogens. J Agric Food Chem 2004;52:8255-60.

10. Baydar H, Sağdic $\mathrm{O}$, Özkan K, Karadoğan T. Antibacterial activity and composition of essential oils from Origanum, Thymbra and Satureja species with commercial importance in Turkey. Food Control 2004;15:169-72.

11. Berber VB, Gomes BP, Sena NT, Vianna ME, Ferraz CC, Zaia AA, et al.
Efficacy of various concentrations of $\mathrm{NaOCl}$ and instrumentation techniques in reducing Enterococcus faecalis within root canals and dentinal tubules. Int Endod J 2006;39:10-7.

12. Teixeira CS, Felippe MC, Felippe WT. The effect of application time of EDTA and $\mathrm{NaOCl}$ on intracanal smear layer removal: An SEM analysis. Int Endod J 2005;38:285-90.

13. Johal S, Baumgartner JC, Marshall JG. Comparison of the antimicrobial efficacy of $1.3 \% \mathrm{NaOCl} / \mathrm{BioPure}$ MTAD to $5.25 \% \mathrm{NaOCl} / 15 \%$ EDTA for root canal irrigation. J Endod 2007;33:48-51.

14. Peciuliene V, Reynaud AH, Balciuniene I, Haapasalo M. Isolation of yeasts and enteric bacteria in root-filled teeth with chronic apical periodontitis. Int Endod J 2001;34:429-34.

15. Sundqvist G, Figdor D, Persson S, Sjögren U. Microbiologic analysis of teeth with failed endodontic treatment and the outcome of conservative re-treatment. Oral Surg Oral Med Oral Pathol Oral Radiol Endod 1998;85:86-93.

16. Nagaoka S, Miyazaki Y, Liu HJ, Iwamoto Y, Kitano M, Kawagoe M. Bacterial invasion into dentinal tubules of human vital and nonvital teeth. J Endod 1995;21:70-3.

17. Buck R, Eleazer PD, Staat RH. In vitro disinfection of dentinal tubules by various endodontics irrigants. J Endod 1999;25:786-8.

18. Vahdaty A, Pitt Ford TR, Wilson RF. Efficacy of chlorhexidine in disinfecting dentinal tubules in vitro. Endod Dent Traumatol 1993;9:243-8.

19. Gomes BP, Souza SF, Ferraz CC, Teixeira FB, Zaia AA, Valdrighi L, et al. Effectiveness of $2 \%$ chlorhexidine gel and calcium hydroxide against Enterococcus faecalis in bovine root dentine in vitro. Int Endod J 2003;36:267-75.

20. Mohammadi Z, Shahriari S. Residual antibacterial activity of chlorhexidine and MTAD in human root dentin in vitro. J Oral Sci 2008;50:63-7.

21. Basrani B, Santos JM, Tjäderhane L, Grad H, Gorduysus O, Huang J, et al. Substantive antimicrobial activity in chlorhexidine-treated human root dentin. Oral Surg Oral Med Oral Pathol Oral Radiol Endod 2002;94:240-5.

22. Beltz RE, Torabinejad M, Pouresmail M. Quantitative analysis of the solubilizing action of MTAD, sodium hypochlorite, and EDTA on bovine pulp and dentin. J Endod 2003;29:334-7.

23. Khademi A, Yazdizadeh M, Feizianfard M. Determination of the minimum instrumentation size for penetration of irrigants to the apical third of root canal systems. J Endod 2006;32:417-20.

24. Marending M, Paqué F, Fischer J, Zehnder M. Impact of irrigant sequence on mechanical properties of human root dentin. J Endod 2007;33:1325-8.

25. Franchi M, Eppinger F, Filippini GF, Montanari G. NaOCl and EDTA irrigating solutions for endodontics: SEM findings. Bull Group Int Rech Sci Stomatol Odontol 1992;35:93-7.

26. Serper A, Calt S. The demineralizing effects of EDTA at different concentrations and $\mathrm{pH}$. J Endod 2002;28:501-2.

27. Ahmetoglu F, Keles A, Yalcin M, Simsek N. Effectiveness of different irrigation systems on smear layer removal: A scanning electron microscopic study. Eur J Dent 2014;8:53-7.

28. Ballal NV, Kandian S, Mala K, Bhat KS, Acharya S. Comparison of the efficacy of maleic acid and ethylenediaminetetraacetic acid in smear layer removal from instrumented human root canal: A scanning electron microscopic study. J Endod 2009;35:1573-6.

29. Torabinejad M, Shabahang S, Aprecio RM, Kettering JD. The antimicrobial effect of MTAD: An in vitro investigation. J Endod 2003;29:400-3.

\begin{tabular}{|l|l|}
\hline \multicolumn{2}{|c|}{ Access this article online } \\
\hline Quick Response Code: & Website: \\
& www.eurjdent.com \\
\cline { 2 - 2 } & \\
\hline
\end{tabular}

